\title{
WORK LIFE BALANCE AND WORKING INDIAN MOTHERS: AN EMPIRICAL STUDY
}

\author{
Dr.Nivedita Pandey \\ Research Scholar \\ University of Rajasthan, Jaipur, Rajasthan, India
}

\author{
Madhuri Dhanopia \\ Research scholar \\ University of Rajasthan, Jaipur, Rajasthan, India
}

\begin{abstract}
Indian society too has undergone many changes. Indian women have become very aware of their rights. Now she does not want to depend on her husbands, for this she tries to be selfsufficient and independent. But the circumstances are not so simple. Managing work and family responsibility can be very difficult for the women employees. And if the woman is a mother, things get even more difficult, because responsibility also gets bigger. A woman who work or do any business or other work especially working mothers has to perform multiple roles in balancing their work life and personal life. Each role has its own set of demands and when such role demand overlaps/interacts, a difference is created leading to stress, attrition, absenteeism and other health issues etc. Thus, there is an increasing need for organizations to address these demands of working mothers by implementing innovative HR policies. Worklife balance is one such HR practice that enables the employees particularly working mothers to give proper prioritization between work and lifespan roles. Hence, work-life balance has become a growing concern in all the sectors. Indian women have created a history in every domains of life today. She is now more being confident and positive.
\end{abstract}

The present paper based on empirical research, delivers a deep insight of work-life balance of working mothers the problems faced by them in different phases of life. With the passage of time the relevance of work life balance becomes very important for working women when family responsibilities increase and care for children and other dependent become priority

Keywords - HR policies, Absenteeism, Work-life balance, HR practice

\section{INTRODUCTION}

As we all very much aware about the work life balance.it is a major issue of all our lives. We all probably always try to manage our lives and work in some way in daily basis. There is no perfect definition of any things. Everyone has their own viewpoint or we can say perception. Here is some definition given by the different researchers.

\begin{tabular}{|c|c|c|c|}
\hline $\begin{array}{c}\text { SERIAL } \\
\text { NO }\end{array}$ & $\begin{array}{c}\text { AUTHOR } \\
\text { NAME }\end{array}$ & YEAR & $\begin{array}{c}\text { DEFINATION } \\
\text { Osterman }\end{array}$ \\
\hline 1 & 1995 & $\begin{array}{c}\text { Work life balance plans } \\
\text { are those institutionalized } \\
\text { structural and procedural } \\
\text { arrangements, as well as } \\
\text { formal and informal } \\
\text { Practices that make it } \\
\text { easier for individuals to } \\
\text { manage the often- } \\
\text { conflicting worlds of } \\
\text { work and family lives. }\end{array}$ \\
\hline 2 & $\begin{array}{c}\text { Greenhaus, } \\
\text { Collins } \& \\
\text { Sawh }\end{array}$ & 2003 & $\begin{array}{c}\text { Work life balance as the } \\
\text { extent to which an } \\
\text { individual is equally-self } \\
\text { engaged and equally } \\
\text { satisfied with -his or her } \\
\text { work role and family } \\
\text { role". Work-life balance } \\
\text { does not mean an equal } \\
\text { balance in units of time } \\
\text { between work and life. It } \\
\text { is not a tight rope walk } \\
\text { between two poles acting } \\
\text { as an organizational } \\
\text { commitments and home } \\
\text { demands at the same } \\
\text { time, but it is about } \\
\text { proper understanding of } \\
\text { the priorities of the } \\
\text { professional and personal } \\
\text { level. }\end{array}$ \\
\hline 3 & Hudson & 2005 & $\begin{array}{c}\text { Work-life balance, in its } \\
\text { broadest sense, is defined } \\
\text { as a satisfactory level of } \\
\text { involvement or 'fit' } \\
\text { between the multiple } \\
\text { roles in a person's life. }\end{array}$ \\
\hline
\end{tabular}




\section{International Journal of Engineering Applied Sciences and Technology, 2019 \\ Vol. 4, Issue 7, ISSN No. 2455-2143, Pages 119-124 \\ Published Online November 2019 in IJEAST (http://www.ijeast.com)}

\begin{tabular}{|c|c|c|c|}
\hline 4 & Johnson & 2005 & $\begin{array}{l}\text { The employees' age, } \\
\text { lifestyle, and environment } \\
\text { play important role in } \\
\text { one's perception of work- } \\
\text { life balance. }\end{array}$ \\
\hline 5 & Gibson & 2006 & $\begin{array}{l}\text { He offered two } \\
\text { explanations regarding the } \\
\text { interconnectedness of } \\
\text { work and life in the } \\
\text { organizational setting: } \\
\text { 1) The compensation } \\
\text { effect implies that } \\
\text { employees tend to } \\
\text { compensate for low work } \\
\text { or personal life } \\
\text { satisfaction by seeking } \\
\text { contentment in the other } \\
\text { domain; and } \\
\text { 2) The spillover view that } \\
\text { indicates that job } \\
\text { satisfaction spills over } \\
\text { into one's work life and } \\
\text { vice versa }\end{array}$ \\
\hline
\end{tabular}

\section{WORKING MOTHERS \& WORK LIFE BALANCE}

Working women are really a good manager, who can manage everything and anything. They are truly a fighter, who can fight against any odds. We are living in Indian society; we have given women the status of goddess. But one pathetic side is also we don't treat women well. India is a male dominated country.

Here man attains the highest position in family and the woman is responsible for all the household as well as outside work. For men it is so casual to work and make a mark at the end of the day that he has done a great job and he is more tired of his work, and is left with no energy to work inside the house, but working women in a way are required to play numerous roles. As the women has stepped out to work she has invited more worries and responsibilities to work on, and hence she lacks in some of the areas of her field and leads to a frustrated and unhappy life.

Work-life balance is somewhat every person struggles for, but it's increasingly difficult for women, especially for working mothers, Women try to be super wives, super moms, and career women. If seen, this is so difficult. Women also take care of their in-laws', Also helps husband, she also watches household chores and she also looks after the children herself 'after this. She also jobs outside. And also performs her job responsibilities well.
In today's era, balancing family and work is a challenge for women. Women struggle to keep pace with men on this measure as they begin to juggle work and family life. It has never been easy for women to juggle a thriving career and a happy family life. It still isn't because being a full-time working mom comes with bouts of stress and guilt for not being able to give equal time to work and family. This being said, it's 21 st century and women from all walks of life are choosing to have it all — a blissful family, a rewarding career and some solitude to find some time for themselves.

May be every working women struggle in striking the right work-life balance post marriage, but as we know that resilience is one of the greatest strengths of a woman. For maintaining work-life balance requires constant adjustments, compromises, and sacrifices.

The present study gives a comparative analysis of work-life balance among working mothers at various age levels. The researchers on work-life balance among women employees found that female employees face the problem of balancing personal and family life, out of which more imbalance is observed in married women due to more family responsibilities.

Organizations always seek employees who are more flexible, productive and who can adjust to the business world. Work pressure, long working hours, night shifts, insufficient holidays, pressure to complete the tasks in time due to cut throat competencies etc., create an imbalance in work-life as well as family life. This results in a smaller amount of productivity at workplace, giving way for absenteeism, high attrition, low morale, high employee turnover etc.

\section{OBSTACLES FOR WORKING MOTHERS IN MAINTAINING WORK LIFE BALANCE}

This new generation of women wants to set an example of her perfection and has to find keys for a balance work life. Just being a trained homemaker will not serve the demand of the hour she has to stake equal and much higher roles at par with their male counterparts. Today women in India are also facing lot of dilemmas in chasing a smooth work life balance. 
International Journal of Engineering Applied Sciences and Technology, 2019

Vol. 4, Issue 7, ISSN No. 2455-2143, Pages 119-124

Published Online November 2019 in IJEAST (http://www.ijeast.com)

\begin{tabular}{|c|c|c|}
\hline S.NO & $\begin{array}{l}\text { PROFESSIONALLY } \\
\text { OBSTACLES }\end{array}$ & $\begin{array}{l}\text { PERSONAL } \\
\text { OBSTACLES }\end{array}$ \\
\hline 1 & INFLEXIBLE TIME & $\begin{array}{l}\text { LACK OF FAMILY } \\
\text { SUPPORT }\end{array}$ \\
\hline 2 & $\begin{array}{l}\text { DISCRIMINATION IN WORK } \\
\text { PLACE }\end{array}$ & $\begin{array}{l}\text { NO SAFETY OF } \\
\text { WORKING } \\
\text { WOMEN WHILE } \\
\text { TRAVELLING }\end{array}$ \\
\hline 3 & OCCUPATIONAL PROBLEMS & $\begin{array}{l}\text { PERSONAL } \\
\text { INCOME }\end{array}$ \\
\hline 4 & MENTAL HARASSMENT & AGE \\
\hline 5 & SEXUAL HARASSMENT & $\begin{array}{l}\text { MATRIMONIAL } \\
\text { STATUS }\end{array}$ \\
\hline 6 & JOB INSECURITY & $\begin{array}{l}\text { NUMBER OF } \\
\text { CHILDREN }\end{array}$ \\
\hline 7 & WORKPLACE ADJUSTMENT & $\begin{array}{l}\text { LEVEL OF } \\
\text { EDUCATION }\end{array}$ \\
\hline 8 & LOW SALARY AND WAGES & $\begin{array}{l}\text { SINGLE PARENT } \\
\text { FAMILIES }\end{array}$ \\
\hline 9 & $\begin{array}{c}\text { WORK POSITION FEATURES } \\
\text { LIKE JOB OCCUPANCY, SIZE } \\
\text { OF EMPLOYING } \\
\text { ORGANIZATION, HOURS } \\
\text { WORKED FOR EVERY WEEK }\end{array}$ & $\begin{array}{l}\text { DUAL CAREER } \\
\text { FAMILIES }\end{array}$ \\
\hline 10 & WORK LOAD & $\begin{array}{c}\text { TiME } \\
\text { MANAGEMENT }\end{array}$ \\
\hline
\end{tabular}

To maintain work life balance, firstly we have to balance these two types of barriers. To overcome from these professionally and personally obstacles is very important and necessary. They have to equally distribute their personal \& professional life in order to maintain a smooth and happy life. Indian women are still detained with the backwardness of people and still have lot of risk in this man dominating world to come out successful. The difficulties in her path are, job insecurity, salary inequality, mental and sexual harassments, lack of support at work and unsupportive family and in taking the care of family and society restrictions etc.

Professional working mother in India are still doing three jobs - office, housework and child care. Professional women hardly find space for themselves to accomplish basic essential of life

like sufficient sleep, workout and a healthy diet. Physical \& mental stress leads psychological effect among working mothers.

\section{WORK LIFE BALANCE PRACTICES IN INDIA}

Just a few days ago there has been a study on work life balance in JAPAN; according to that report if employees work only four days in a week then their productivity will increase. This is the international research on work life balance. Here are we are discussing the work life balances practices in India.

A pleasant working environment, flexible working hours and workplaces, work from home, medical facilities, women friendly policies, supportive working environment \& team, better communication policies keeps women employee highly motivated.

At a time when work-related stress is taking a toll on the life of employees, it is refreshing to see some companies go out of the way to make their staff love the work they do and also ensure they have a great work-life balance.

Here is a list of some companies and their key factors, which makes them in pioneer in work life balance practices in India.

\begin{tabular}{|c|c|c|}
\hline $\begin{array}{l}\text { RAN } \\
\text { K }\end{array}$ & $\begin{array}{l}\text { COMPANIE } \\
\text { S NAME }\end{array}$ & $\begin{array}{l}\text { WORK LIFE BALANCE-KEY } \\
\text { FACTORS }\end{array}$ \\
\hline 1 & RMSI & $\begin{array}{l}\text { Rewarding environment } \\
\text { Healthcare and other } \\
\text { benefits } \\
\text { Initiatives for women--Anti } \\
\text { sexual harassment' policy } \\
\text { The music band, } \\
\text { photography club, painting, } \\
\text { acting, movie making, } \\
\text { guitar classes, zumba } \\
\text { lessons, sports tournaments }\end{array}$ \\
\hline 2 & Google India & $\begin{array}{l}>\text { Fitness and fun are woven } \\
\text { into Google's history } \\
\text { Access to best facilities } \\
>\text { Fun at work } \\
>\quad \text { Fomen's initiatives } \\
\text { Food - Three meals and } \\
\text { unlimited snacks from the } \\
\text { cafeteria are totally free of } \\
\text { cost. } \\
>\text { For families - Involving } \\
\text { families, Google hosts its } \\
\text { annual 'bring your children } \\
\text { to work' day. On this day, } \\
\text { the company organizes } \\
\text { engagement activities for } \\
\text { children. }\end{array}$ \\
\hline
\end{tabular}


International Journal of Engineering Applied Sciences and Technology, 2019

Vol. 4, Issue 7, ISSN No. 2455-2143, Pages 119-124

Published Online November 2019 in IJEAST (http://www.ijeast.com)

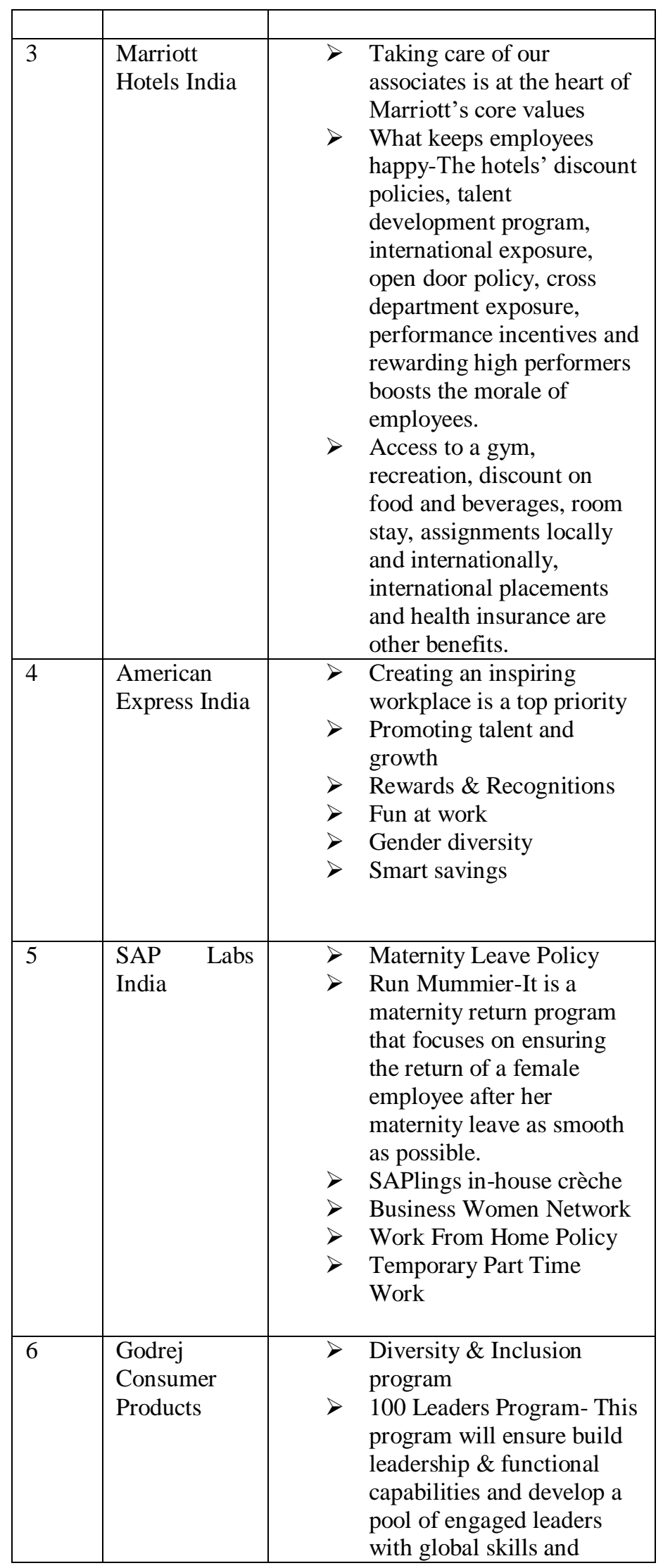

\begin{tabular}{|c|c|c|c|}
\hline & & & $\begin{array}{l}\text { mindsets. } \\
\text { Maternity policy } \\
\text { Godrej LOUD (Live out Un } \\
\text { Dream) is a new approach } \\
\text { to spotting and attracting } \\
\text { talent at business school in } \\
\text { India. }\end{array}$ \\
\hline 7 & $\begin{array}{l}\text { Intuit } \\
\text { Technology } \\
\text { Services }\end{array}$ & & $\begin{array}{l}\text { Diverse Workforce } \\
\text { Maternity \& Paternity } \\
\text { Leave } \\
\text { Medical Insurance } \\
\text { Innovation At Intuit }\end{array}$ \\
\hline 8 & $\begin{array}{l}\text { Accor Hotels } \\
\text { India }\end{array}$ & $>$ & $\begin{array}{l}\text { Creating a caring and } \\
\text { inspiring workplace } \\
\text { Creating a culture where } \\
\text { people have the freedom to } \\
\text { exemplify their best work } \\
\text { practices in an environment } \\
\text { they enjoy. } \\
\text { Its policies are based on } \\
\text { professionalism, } \\
\text { recognition, diversity and } \\
\text { respect. }\end{array}$ \\
\hline 9 & $\begin{array}{l}\text { Forbes } \\
\text { Marshall }\end{array}$ & $>$ & $\begin{array}{l}\text { Communications are } \\
\text { transparent and accessible } \\
\text { High credibility, respect, } \\
\text { fairness, pride and } \\
\text { camaraderie policies. } \\
\text { Equitable and impartial } \\
\text { practices. }\end{array}$ \\
\hline 10 & $\begin{array}{l}\text { Lifestyle } \\
\text { International }\end{array}$ & $>$ & $\begin{array}{l}\text { A culture of openness, } \\
\text { transparency, camaraderie, } \\
\text { trust } \\
\text { Employee friendly } \\
\text { initiatives } \\
\text { whistle blower policy-To } \\
\text { encourage transparency, } \\
\text { the company has a whistle } \\
\text { blower policy } \\
\text { Work force diversified } \\
\text { policy }\end{array}$ \\
\hline
\end{tabular}

V. CONCLUSION

Conventionally in our society people think that men should only work and gain money and women should work as house hold, but the modern era and financial demands on the Indian families are increasing that's why women also should company in earning income for families. Therefore an important change is required in attitudes of employees, family members and public. 


\section{International Journal of Engineering Applied Sciences and Technology, 2019 \\ Vol. 4, Issue 7, ISSN No. 2455-2143, Pages 119-124 \\ Published Online November 2019 in IJEAST (http://www.ijeast.com)}

Here are some important work life balances practices, which are followed by today's organizations. These practices always help working mothers to make coordination between personal and professional front.

Pre and post maternity leave is very common and important issue for every working woman. Most of the good organization offers effective maternity policy to their women employees. The company's maternity policy offers full pay for six months. Women employees are entitled to twenty weeks of paid maternity leave with an additional sixteen weeks of extended maternity leave with loss of pay or a part time work option. Women are offered with cab transportation during and post pregnancy.

Run mummier program: It is a maternity return program that focuses on ensuring the return of a female employee after her maternity leave as smooth as possible.

In-house crèche: This crèche caters to 250 children in the age group of nine months to six years. Under this program children are provided with day care, Montessori education, summer camps as well as other activities.

Part time work from home after the birth of a child implies that male employees, apart from paternity leave, have the flexibility to work for four hours at office and the rest from home.

They are endeavoring to create an open and inclusive environment for our women talent, who return to work post an extended break.

Flexi work and part time work options are also available to help make this balance along with other facilities at our offices. A robust talent management process to groom high potential women talent.

Many organizations are also starting to create goals for their selves in terms of female representation in our workforce and at different managerial levels.

As numerous enterprises are moving forward and taking steps to improve the working condition of the women at different workplace similarly the families members also need to understand the situation. They should also help in household chores with working women and also provide mental and emotional support to her. This will also improve the family environment. Family support is the absolute most asset for any working women, if the healthy and peaceful work environment is maintained in the house, not only the efficiency of a women increases but also supports other family members to work hard and develop great bond.
There is also a saying that god helps those who help themselves. Government and many organizations have taken lot of steps to improve the condition of working women in the form of statutory and non-statutory practices. But no one can help women unless she has a strong will power. Here are some recommendations that every working woman should follow at individual level to maintain balance between professional and personal front.

$>$ Set you priorities firstly.

$>$ Make some time for yourself.

$>$ Draw a border line between home and work.

$>$ Proper communication with your employers.

$>$ Appropriate time management.

$>$ Learn the art of delegation.

$>$ Maintain a strong will power.

\section{REFERENCES}

1)Chawla,Deepak and Sondhi Neena (2011), “Assessing Work-Life Balance Among Indian Women Professionals", The Indian Journal of Industrial Relations, 47(2): 341-351.

2)Friedman S.D., Christensen P. and DeGroot J. 1998. Work and Life, The End of the Zero-Sum Game, Harvard Business Review, Nov-Dec, pp.119-129.

3)Greenhaus, J.H, Collins,K.M. and Shaw, J.D(2003), "The Relation Between Work -Family Balance and Quality of Life", Journal of Vocational Behaviour,63:510-531.

4)Lockwood, Nancy R. (2003), "Work/life Balance: Challenges and Solutions," Stratgic Human Resouces Management Journal, 48.6, pp.81-90.

5)Luthans, F. (1998), Organizational Behavior, 8th Ed.,Irwin McGraw-Hill, Boston.

6)Madipelli,Saritha., V.S.Veluri Sarma \& Y.Chinnappaiah (2013), "Factors Causing Work Life Imbalance among Working Women-A Study on School Teachers", The Indian Journal of Industrial Relations, 48(4): 612-633.

7)Mehta, Vijayashree.(2012), A Study of Work Life Balance Among Women Employees in Service Sector With Special Reference to Pune city, Unpublished Ph.D. Dissertation submitted to Department of Management, Pune Univesity,Pune.

8). Parida Sarit Sambit , (2016)," Work life Balance Practices in India”, IJARIIE-ISSN(O)-2395-4396, Vol-2 Issue-6. 
9)Parus, B. (2000), "Measuring the ROI of Work/life Programs," Work-span, 43.9, pp. 50-54.

10) S,Susi and Jawaharrani.k. (2010), "Work life Balance: The Key Driver of Employee Engagement", Asian Journal of Management Research, 2(1):474483.

11) Sinha Deepti (2013), Study of Work Life Balance @ CCIL (India), NOIDA, Journal of Management Sciences And Technology.

12) http://www.womensforum.in/working-mums/1186challenges-faced-working-women-india.html.

13) http://www.womenpaycheck.in/main/glass-ceilingfor-women-in-the-workplace.

14) www.rediff.com.

15) Blog: visionsaheadbykavitathapliyal.blogspot.com 